\title{
A Big House Divided: Images of Irish Nationhood in Edna O'Brien's House of Splendid Isolation
}

Jennifer A. Slivka

\section{(2) OpenEdition \\ 1 Journals}

\section{Electronic version}

URL: http://journals.openedition.org/etudesirlandaises/5926

DOI: 10.4000/etudesirlandaises.5926

ISSN: 2259-8863

\section{Publisher}

Presses universitaires de Caen

\section{Printed version}

Date of publication: 18 December 2018

ISBN: 978-2-7535-7693-3

ISSN: 0183-973X

\section{Electronic reference}

Jennifer A. Slivka, «A Big House Divided: Images of Irish Nationhood in Edna O'Brien's House of

Splendid Isolation », Études irlandaises [Online], 43-2 | 2018, Online since 01 November 2018, connection on 13 September 2019. URL : http://journals.openedition.org/etudesirlandaises/5926; DOI : 10.4000/ etudesirlandaises.5926

This text was automatically generated on 13 September 2019.

(c) Presses universitaires de Rennes 


\title{
A Big House Divided: Images of Irish Nationhood in Edna O'Brien's House of Splendid Isolation
}

\author{
Jennifer A. Slivka
}

1 Demands for stronger borders are often framed as preserving and unifying national culture, but in actuality, operate as a way to allay fears of invasion from an external antagonist. But as Edna O'Brien's fiction demonstrates, the antagonist is not always foreign, nor do borders simply control who enters or leaves. Kathryn Conrad notes that borders are "way[s] to imagine the limits of power, mobility, and the body in space"; in particular, the body borders of Irish women have long been "site[s] of ideological battle". Similar to other postcolonial nations, Irish women have a long history of being "bearers of national culture"; indeed, Elleke Boehmer observes that "woman-as-sign buttresses national imagining [...] gender has been to date, habitual and apparently intrinsic to national imagining" for postcolonial nations, to the extent that "nationalism and gender have been deployed mutually to invoke and constitute one another (while at the same time being constituted [...] in relation to other categories of difference also) ${ }^{2 \prime}$. What results from this perverse symbiosis, then, are nationalist gender ideologies that police, silence, and/or simplify women's lived experiences in order to support the engendering of a "national imaginary." o'Brien's fiction seeks to dismantle nationalist conceptions of Irish womanhood, most notably in her later trilogy-House of Splendid Isolation (1994), Down by the River (1997), Wild Decembers (2001), and thematically, I am including In the Forest (2002)-which exposes Ireland as a nation in crisis by portraying the home-asnation as an unhomely one. ${ }^{3}$ These crises are brought about through the uncanny, which Freud defines as "everything that was intended to remain secret, hidden away, and has come into the open". In O'Brien's fiction, this surfaces across three spatial registers of "home": the self, the familial home, and the nation. 


\section{A Divided Nation, Home, and Self}

2 In House of Splendid Isolation (1994), O'Brien traps two marginalized figures under a state of emergency in a dilapidated Big House, with the isolated house serving as a microcosm for the imagined community of the nation. The house and its occupants reflect the borders between North and South, past and present ${ }^{5}$. O'Brien emphasizes spatiality over temporality in order to subvert the authority of dominant history, especially regarding Irish women's history and the conflict in the North. In this regard, the novel can be read as an indictment against what Joe Cleary defines as the "revisionist critique of revolutionary nationalism", which attempts to

integrate the state into the global capitalist economy and the European Union [by] redefining the "Irish nation" in order to make it coterminous with the Southern Irish state-thereby divesting that state of the awkward "supplement" of the Catholic nationalists in the North ${ }^{6}$.

Through O'Brien's rounded depiction of McGreevy, an IRA gunman on the run, she also critiques the Republic of Ireland's "strategies and ideologies of containment designed to downplay as much as possible their own involvement in the struggle and to suggest that its roots lay exclusively in the intractable sectarianism of Northern Ireland's hostile communities". Julia Kristeva's discussion of the Freudian uncanny provides another way to address the conflict presented in O'Brien's novel by stressing how:

the narcissistic self, not yet demarcated by the outside world, projects out of itself what it experiences as dangerous or unpleasant in itself, making of it an alien double , uncanny and demoniacal [...] the strange appears as a defense put up by a distraught self: it protects itself by substituting for the image of a benevolent double that used to be enough to shelter it the image of a malevolent double into which it expels the share of destruction it cannot contain. ${ }^{8}$

In House, the Irish nation operates as the "narcissistic self" still trying to define or "demarcate" itself in the global community. As a result, it expels "dangerous or unpleasant" figures such as Josie O'Meara and McGreevy out of its dominant culture. On a larger scale, McGreevy, as a symbol of the chaotic North, is rendered a "demoniacal" double by the press and the gardaí. According to Jean and John Comaroff, the "spectacle of policing" is staged in postcolonies "to make actual, both to its subjects and to itself, the authorized face, and force, of the state-of a state, that is, whose legitimacy is far from unequivocal". In other words, the "benevolent double" image that Ireland creates to sustain itself is not enough; it must visibly vilify and sacrifice the Other within (e.g., Josie and McGreevy) as a way to purge its own demons.

Spaces are never neutral; they are ideological sites where dominant cultural paradigms are conceived, perceived, and contested. According to Sara Mills, "space is a question of relations: perceptions of and actual relations between the individual, the group, institutions and architecture or access ${ }^{10}$ ". In House, the different registers of home can be read through Edward Soja and Henri Lefebvre's "trialectics of spatiality" in which social space comprises three dimensions: perceived space (Firstspace), representations of space (Secondspace), and spaces of representation (Thirdspace). In House, the Firstspace, or "repetitive routines of everyday life" include that which "can be measured", such as the house itself as well as Josie's body ${ }^{11}$. Secondspace, or conceptualized space, is "entirely ideational, made up of projections into the empirical world from conceived/imagined geographies" which Soja asserts tend "to become the 'real' geography, with the image or 
representation coming to define and order the reality". In O'Brien's novel, these "mental spaces", or what "[Lefebvre] called the dominant space, surveying and controlling both spatial practices and the lived spaces of representation ${ }^{13}$ " are the gender ideologies that police and oppress. But it is Thirdspace, or "space as directly lived" that is the "terrain for the generation of 'counterspaces,' spaces of resistance to the dominant order arising precisely from their subordinate, peripheral or marginalized positioning", in which Josie and McGreevy's characters are used to critique the oppressive nationalist ideologies which manifest in "Firstspace and Secondspace modes of thought ${ }^{14}$ ".

6 In O'Brien's novel, the home-as-nation becomes a contested borderland when an isolated widow and an IRA gunman from Northern Ireland are forced to live together when he holds her hostage in order to use her home as a "safe house", which assumes multiple, and often ironic connotations in the novel. Gloria Anzaldúa defines borderlands as being present

wherever two or more cultures edge each other, where people of different races occupy the same territory, where under, lower, middle and upper classes touch, where the space between two individuals shrinks with intimacy ${ }^{15}$.

7 Although race is a critical aspect to Anzaldúa's theory, this essay expands her concept by defining borderlands as spaces where subjects differing in age, gender, and place come into contact ${ }^{16}$. Through a relationship transcending their differences, they free themselves from societal strictures that have been imposed upon them. These figures are what Anzaldúa would characterize as "border" people, as they are marginalized by the patriarchal state because they defy laws of state and gender. As these figures cross literal and figurative borders, a crisis occurs when the personal trauma of the characters collides with the social trauma of the Irish homeland, thereby dispelling the fantasy of a stable, national narrative. What I want to argue, then, is that although new or denied identities have the possibility to emerge, spatial and temporal crossings expose the fragility of the nation, the familial home, and ultimately, the self. Although O'Brien locates a possibility of understanding and reconciliation through their brief contact, the violence of the patriarchal state closes down the sustainability of their border crossing. By elaborating the ways in which O'Brien's dilapidated Big House becomes an uncanny borderland, this essay critically unpacks the ways in which the Irish nation attempts to define itself by "evicting" those who disrupt the laws of state and gender.

The inequities of the prevailing gender ideology, despite shifts in time periods, are revealed in the contrast between public and private spheres, as Soja asserts that "space can be made to hide consequences from us, how relations of power and discipline are inscribed into the apparently innocent spatiality of social life ${ }^{17 "}$. The exteriority of the Big House belies a private abusive prison when Josie's husband's initial magnanimity gives way to oppressive brutality. O'Brien revises the Big-House subgenre associated with the Anglo-Irish Ascendancy class-the decline and eventual destruction of the house and the paternalism of its new Irish Catholic owner reveal that independence merely resulted in "a reconfiguration of oppression ${ }^{18}$ ". For example, Kevin O'Higgins, Minister for Justice in the mid-1920s, said, "a few words in a Constitution do not wipe out the very real differences between the sexes, either physical or mental or temperamental or emotional ${ }^{19}$ ". Catherine Nash notes how the "discourses that confined women within the domestic sphere simultaneously conferred on them the responsibility of maintaining the national population"; their function was to "reproduce the bodies of the "body politic' represented as masculine ${ }^{20}$ ". Josie's initial visions of becoming her own mistress of an expansive house 
dissolve quickly with the realization that she is merely an object of exchange, as her marriage to Jamie ensures her aunt and uncle land usage. Here, control of landscape is directly linked to control over the female body. When Josie does not bear him an heir, Jamie drinks heavily and becomes sexually vicious in order to assert his authority. Danine Farquharson and Bernice Schrank describe Jamie's duality:

Having rejected imperialism in the public domain, Jamie, in many ways a typical Irish man of nationalist sympathies, reenacts the imperial impulse in sexual terms, appropriating for himself the role of colonizer in his bedroom ${ }^{21}$.

During the 1920s, "where a wife was found to be barren (and it was believed that this was the wife's problem solely), it was perfectly acceptable for the husband to beat her ${ }^{22}$ ". But Jamie does not simply beat Josie; "He has taken to holding her lips shut with one hand [...] he likes the power he has over her [...] as he endeavours to prise her apart, go right into her [...] as what, a babby maybe ${ }^{23}$ ". "Holding her lips shut" silences any sort of refusal and "pris[ing] her apart" denies Josie sexual pleasure. Yet she refuses to completely submit to the function of Irish womanhood by producing future sons of the nation. Instead, she aborts Jamie's child in an effort to control her body and to rebel against his abuse by denying him an heir. In aborting her only child, Josie's character can be read as a satirical revision of Kathleen ni Houlihan, the young/old woman symbolizing Ireland who lures young Irish men to die for her. But in this case, the sacrifice is not for the nation that she is supposed to represent and reproduce, it is in rebellion against it. ${ }^{24}$ Still, O'Brien reveals that abortion is not an easy solution either, as Josie is burdened with a lifetime of guilt and is further isolated within her marital home.

10 The house, as "spatialization of patriarchal power"25", entraps and isolates its female occupant, paradoxically serving as haven and prison for her, much like her own body. Here, O'Brien purposefully conflates the house with Josie's body in an ironic re-visioning of the woman-as-nation trope through what Barbara Hooper calls "somatography":

It is a concrete physical space of flesh and bone [...] it is a highly mediated space, a space transformed by cultural interpretations and representations; it is a lived space, a volatile space of conscious and unconscious desires and motivations-a body/self, a subject, and identity: it is, in sum, a social space, a complexity involving the workings of power and knowledge and the workings of the body's lived unpredictabilities ${ }^{26}$.

The fact that both Josie and the house are uncannily awakened by a young priest's arrival makes visible sexual desire that is supposed to be suppressed and repressed according to the Catholic Church. O'Brien's conflation of Josie with the home of the nation further satirizes Josie's character as a representation of Mother Ireland, a supposedly chaste maternal symbol of the nation: "The drawing room had never heard such words and the silverware and pewter responded to them, and in the grate a swag of orange gold fluttered merrily up the chimney" $(H, 136)$. Upon discovering Josie's wish to marry to $\mathrm{Fr}$ John, Jamie traps her as she attempts to escape from the house. ${ }^{27}$ Josie, "naked and cut, asprawl a windowsill" is violently caught along the threshold between the prison of the house, i.e., Firstspace and Secondspace, and the exterior landscape, which represents the possibility of a different life or Thirdspace, free from such oppression.

McGreevy's invasion also causes her to escape from the prison of her body. But unlike the sexualized effect of Fr John, McGreevy's "coming has brought menace into the air", as the "landscape seems alien, sod and grass feel different" $(H, 87)$. Josie's body mirrors the landscape's uncanny changes, too. In the beginning of the novel, Josie is physically weak and dependent, as the 1937 Constitution says she should be. Yet McGreevy's arrival 
awakens a strength she was not supposed to have, as she "was now dragging the brown chest of drawers across the floor" to keep him out of her room $(H, 71)$. There are several ways to read this scene. On the one hand, McGreevy is portrayed as the stereotypical "figure of the archfelon" from the North, but his presence is simultaneously productive since violence "usurps representation, reveals the limits of order ${ }^{28}$ " within the Irish state. And on another level, McGreevy's presence causes an uncanny doubling to occur within Josie: "There are two hers, the one who does not dare to admit that [...] there is a dangerous man [...] and the other her, which contends that she is mistress of the house" ( $H$, 77). Freud posits that the figure of the double reveals the

possibilities which, had they been realized, might have shaped our destiny, and to which our imagination still clings, all the strivings of the ego that were frustrated by adverse circumstances, all the suppressed acts of volition that fostered the illusion of free will ${ }^{29}$.

Unlike her willful silence toward her husband's abuse, i.e., her "illusion of free will", Josie voices her defiance against McGreevy's authoritarianism by hoping the Guards will take him alive so that he will "relive every second of every crime" $(H, 119)$.

But O'Brien demonstrates that men are also (mis)shapen by nationalist gender ideologies. Known as both "the Beast" and as a perverse Cúchulainn traveling the length of Ireland eluding capture, McGreevy is transformed into something Other than human. Cleary states there are

essentially two kinds of nationalism [...] that promote two corresponding understandings of nationhood [...] the good civic conception of nationhood [that] is based on common citizenship and the bad ethnic kind [that] is based on common ethnic descent $[. . .]^{30}$.

The latter is viewed as the "badlands of modernity" that aggressively undermines "the saner civic nationalisms of the industrially developed word ${ }^{31}$ ". Thus, the media's depictions of McGreevy as primitive and mythical render him an "unfortunate persistence into the modern of a recalcitrant pre-modern tribalism ${ }^{32}$ ". Ironically, McGreevy is a pariah of the national community for which he fights; he is "Wanted on all sides [...] A bit of a soloist in his deeds" $(H, 113)$. Nothing remains for him in the North: "The certainty" of his cause is "all he has left" $(H, 14)$. As I have argued elsewhere ${ }^{33}$, McGreevy is similar to the marginalized male characters who follow him in O'Brien's oeuvre, in that he reveals the paradox of the exile who exists outside of the community and goes to extreme measures (even destroying that homespace) in order to possess it and the identity he hopes to locate there. According to Kristeva, this type of obdurate fanaticism only surfaces for the exile "when he becomes attached-to a cause [...] What he finds there is more than a country; it is a fusion, in which there are not two beings, there is but a single one who is consumed [...] annihilated ${ }^{34 "}$. In his quest for a unified homeland, McGreevy loses his personal identity to a nationalist one. Cleary notes that

fragmentation is so extensive that it could be argued that since the 1970s the partition of Ireland no longer stopped at the interstate border: the militarization of local territorial boundaries and the increased segregation of its two communities have effectively produced a whole series of internal partitions within Northern Ireland as well ${ }^{35}$.

16 The trope of partition can be seen through McGreevy's dissociation from his own body, telling Josie "hunger is the last thing you feel" $(H, 206)$. This loss of individuality is represented by the national branding epitomized in his tri-color tattoo "and by his name: 
Mc meaning 'son of' and Greevy, a homonym of 'grieve' or 'grief'. Thus McGreevy is the son of grief emanating from the land and its violent history ${ }^{36 "}$.

However, O'Brien's depiction of McGreevy resists the snares of the hypermasculine "freedom fighter/terrorist of the Northern Irish tradition" who "has a tendency to appear as a macho-man in love with guns, [is] naturally violent, [and] sexually disturbed ${ }^{37}$ " by portraying him as a round character who has killed in cold blood, yet panics at the sight of his daughter's coffin and is oddly nurturing and domestic. He cleans Josie's kitchen, fixes her stove, and makes bread; he was also a "model prisoner" and "did the sewing for the others [...] and patched their jeans", but also "arranged for [...] a ton of explosives to be brought in on a digger" to escape from prison (H, 198-199). Through these depictions, O'Brien's text avoids either mythologizing or vilifying him, and suggests that there is more to him than his public persona.

\section{Crossing Borders into (Dis)comfort Zones}

The manner in which the protagonists initially occupy the house is spatially compartmentalized and recalls colonial hierarchy. McGreevy distances himself from Josie because he thinks she is a wealthy Anglo-Irish Protestant, and she capitalizes on his misperception by occupying the top floor bedroom while relegating him to the bottom floor kitchen in order to maintain her authority. Michael Harris suggests that Josie and McGreevy's relationship:

ironically resembles the complex pattern of attraction and repulsion that Bhabha and Robert Young have identified as characteristic of the colonizer-colonized relationship [...] the colonizer's unconscious desire for the colonized Other is expressed through a pattern of sexual attraction and repulsion ${ }^{38}$.

Although a definite attraction and repulsion exists within their relationship, readings such as Harris's limit other possibilities and reduce the significance of their contact. o'Brien revises the popular "romance-across-the-divide" narrative popular in Troubles literature, which focuses heavily on republican violence, portrays the republican nationalist as a "'problem' to which the texts attempt to find 'solutions"' without doing so, and "meld[s] erotic and patriotic desires in narratives that imagine the reconciliation and assimilation of different national constituencies cast as lovers ${ }^{39}$ ". Though some of these features are present in the novel, Josie and McGreevy are not Romeo and Juliet; instead, their friendship is mutually productive in aiding their quest for subjectivity. The novel seems to criticize these traditional literary expectations when the Guards are repulsed at what they perceive is lovemaking when Josie and McGreevy fall to the ground at the sound of a bee that they mistake for the Guards. And spatially, the staircase links the social spaces the characters inhabit within the house, while also linking temporalities between the dead and the living, as Jamie had always heard "chains of the dead" on the last flight of stairs $(H, 78)$. Homi Bhabha asserts, "the un-spoken, unrepresented pasts [...] haunt the historical present ${ }^{40}$ ". O'Brien's novel expresses such temporal hauntings by giving voice to silenced histories, but does so through spatialization.

The fact that McGreevy is able to penetrate the supposed inviolability of the house's isolation, points to the inescapability of the public sphere invading the private sphere. It also draws attention to the "discursive invisibility" of the Irish border promulgated by social forces eager to distance the South from the North by rendering "Northern Ireland as a wholly detached space without a contentious land-border ${ }^{41}$ ". At one point, Josie feels 
the need to help McGreevy in his fight for justice, personal identity, and truth, or as Josie rephrases it-"community" $(H, 105)$. O'Brien's diction is careful and deliberate, as "community" is a flexible term that can be read various ways, e.g., the imagined community of the nation, or a group of individuals with similar or different interests all living together. In this way, "community" can be read as a radical Thirdspace that proffers other modes of lived social space. But O'Brien's fiction never offers easy solutions; their border crossing does not occur easily, as neither Josie nor McGreevy readily yields to the other's viewpoint. Josie gives McGreevy her uncle's diary to show him they share their country's "woes" ( $H, 91)$, but she differentiates the War for Independence from McGreevy's war. This causes him to invoke geographical distance; as a child, McGreevy believed the South was a promised land where "everything was better" $(H, 106)$. But as an adult, he is "aggrieved" that "The South forgot us" $(H, 107)$. Sophia Hillan notes that O'Brien touches "upon a sore place in the Irish psyche, voicing the generally unspoken view that little was done in 1969 by the Dublin government to help the beleaguered and bewildered people of the North ${ }^{42}$ ". The gap between them does not diminish until Josie gives McGreevy Jamie's tackle box, and "Everything happens then; his eyes grateful and shy [...] and something soft and yielding in her bearing" manifests $(H$, 99). The personal sentiment behind this gift exchange overcomes the fragmentation of geo-political borders.

O'Brien undermines another idealized image of the nation, the Irish family, by depicting Josie more at ease as McGreevy's hostage than as a prisoner within her marriage. This is largely due to McGreevy's masculinity, which directly contrasts to Jamie's violent hypermasculinity. When Josie discovers the guns on his bed McGreevy feels obligated to explain himself in a letter, even though it is "against military rules" and apologizes for making her "sick" $(H, 121)$. His vulnerability is laid bare in the "black capitals so small, so helpless" $(H, 122)$. The IRA persona is represented by the dark capital letters (often used for emphasis or authority), yet the size of the letters reveals the fragility underpinning that persona. Josie becomes disoriented when she chases after him "like a mother for an errant but much-loved child ${ }^{43}$ ". She literally and figuratively becomes lost in the fog, falling and stumbling through a "timeless, placeless, featureless world that could be the beginning or the end of creation" $(H, 123)$. She loses her bearings in the borderland existing between strictly defined sides of the war, the law, and gender norms. In order to fully realize her subjectivity, a border figure like Josie

has to 'cross over,' kicking a hole out of the old boundaries of the self and slipping under or over, dragging the old skin along, stumbling over it. It hampers her movement in the new territory dragging the ghost of the past with her ${ }^{44}$.

Indeed, McGreevy finds Josie feverish in the fields, raving about her childhood. Josie cannot navigate this "new territory" by herself; she must rely on another for help, which echoes the joint nature of their Thirdspace "community." McGreevy takes her to a safe house where she regains her physical and emotional self, and thereby reenters the present temporality.

The border crossing occurring within the house undermines each protagonist's identity that they believed to have been solidified within them, though not necessarily by them. Among the women at a local shop, Josie "feels estranged from them all, a criminal" ( $H$, 164). Similarly, McGreevy's accomplices accuse him of "cracking" when he suggests they leave their target to his own demise $(H, 175)$. Like Josie, he also becomes disoriented; "Everything is getting to him, the boundaries of his night askew" $(H, 196)$. He does not 
understand why he returned to the house instead of working out the details of the plan, "a duplicate of himself" $(H, 197)$. Within the borderland of the house, McGreevy has the freedom to become more than a cloned persona. Josie discovers him "defenceless and muttering and insignificant. He had changed his lair to the shoe closet and lay under a shelf doubled up," as if the closet is a surrogate womb around him ( $H, 197)$. The fetal position represents the vulnerability of the self rendered "insignificant" by powerful social forces that (mis)shape it into being.

Anzaldúa describes the process of finding "a way to a new consciousness" as leaving the "the opposite bank, the split between the two mortal combatants somehow healed so that we are on both shores at once", or writing "it off altogether [...] and cross[ing] the border into a wholly new and separate territory ${ }^{45}$ ". This "new consciousness" plays out spatially in the novel, as Josie now allows McGreevy to sleep in one of the upstairs rooms-the border of the staircase no longer separating them ( $H, 217-218)$. His longing to escape captivity and start a family is a catalyst for Josie, as she feels a "Great lunatic fork of longing [...] to be young again, to have wains" $(H, 210)$. Because this is no longer viable for Josie, she maps out an alternative form of motherhood through non-filial caretaking. McGreevy's desperate quest for home inspires her to bequeath the house to "young people [...] for those who travel" $(H, 194)$. Even though her decision is a heteronormative one, it still challenges the idealized family cell, and is of her own choosing. She also desires "to be [her]self again [...] to die whole" $(H, 85)$. McGreevy also considers making a change when Josie prompts him to abandon the war, and he ponders over the two possibilities "the fields and the sheds and the guns; or the inside, a safe inside" $(H, 205)$. These contrasting spaces represent the geography of his psyche; the former represents his public persona, while the latter represents a Thirdspace where his vulnerable self can emerge safely.

But this Thirdspace is thwarted by the arrival of the Guards, who destroy the house and its new possibilities, as the police "embody a nervous state under pressure ${ }^{46 "}$. As the Guards enter the house, Josie becomes an ambiguously gendered figure when she cuts her hair and dons a trench coat in defiance of gender expectations. This causes the Guards to pursue her as a possible outlaw, which is accurate considering she violates the law of gender norms. Josie does not "die whole", at least not physically. She dies as part of the house, being caught between floors when the ceiling gives way with the Guards' shooting. Josie's fall through the ceiling can be read as her crossing borders of class, age, gender, and place, but is killed in the process because she cannot remain a border figure successfully within the home of the nation. Border figures challenge concretized conceptions of national and gender identity, and thus must be eliminated to maintain the status quo. Josie dies, and McGreevy is re-captured and imprisoned.

O'Brien subverts a major symbol of national authority by reversing the threatening figure of the nation; the gardaí invade and damage Josie's house, whereas the criminal is respectful and protective. When McGreevy first invades Josie's home, she imagines the Guards will rescue her with a "helicopter [...] being hoisted up in some kind of cradle" ( $H$, 84). But the Guards only bring her down to her grave. Similarly, their destruction of the nation is portrayed as an uncanny, personified death: "In the back where the explosive went off, wood, metal, and glass are in weird configurations, remainders of wall wobbling like loose teeth in a gum" $(H, 226)$. The Guards seem to grieve more for the ruined house, a microcosm for the nation, than for the dead woman. Before they raid the house, Cormac comments it is a "pity to hurt her", i.e., the house $(H, 218)$. And the main detective is 
angered at how "the beauty and lineaments of the house [are] utterly destroyed, a woman dead, and another notch in the so-called struggle" $(H, 227)$. Despite the loss expressed, Josie is reduced to the gender signifier "woman", unlike the house, which is valued for its "beauty and lineaments." David Lloyd states that political thinking on both sides of the border "perpetuate not only nationalist ideologies, but their articulation along sectarian and, effectively, racial grounds", when the roots of the struggle are the socio-economic conditions of the postcolonial state which have been "systematically obscured ${ }^{47}$ ". This "obscurantism" further perpetuates the notion that Irish history is repetitive due to "the nature of Irish identity ${ }^{48}$ ". Although the narrative of repetitive bloodshed appears in the novel, it seems that British imperialism and Irish Revisionism are held accountable when Josie pronounces there are still two wars: "one with the English and one with ourselves" ( $H, 107)$. After the shootout between the Guards and the IRA, the garda "would never see the face properly; he had not seen it when they tried to slay one another in the crossfire and he does not see it now, match after match sputtering out in the wet" $(H, 192)$. The garda symbolizes the Irish state, which has turned a blind eye to the North and its accountability for the conditions there.

O'Brien leaves us with a cycle of violence by bookending the novel with the voice of Josie's aborted "Child." Though giving subjectivity to an unborn fetus may be read as reifying anti-abortion discourses of the state, the fact that it is an aborted fetus who is speaking is subversive if we consider "the fantasy of the fetus as an uncorrupted and autonomous entity in Irish nationalist, anti-abortion discourse is also a fantasy of the security and autonomy of Ireland. ${ }^{49}$ " Thus, by enclosing the narrative with the aborted Child's voice, O'Brien denies an easy reproduction of Irish nationalism. In some ways, O'Brien's novel appears to reify "the circular and cyclical traumatic paradigm of Irish history" that has been "adopted by many Irish writers 50 ", but her text offers a Thirdspace for escaping this cycle in the border crossing of Josie and McGreevy, which challenges and reimagines the trialectics of spatiality, historicality and sociality. O'Brien's novel contests the "narrative of Irishness", which seems "self-evident, normative, truthful", but in actuality, control of these narratives

is a crucial function of the state apparatus since its political and legal frameworks can only gain consent and legitimacy if the tale they tell monopolizes the field [...] The state does not simply legislate and police against particular infringements, it determines the forms within which representation can take place. ${ }^{51}$

By bringing marginal "infringements" to the center of her narrative, O'Brien demonstrates how the threats of difference have the potential to re-center knowledge formation and the social spaces built around it in order to create a more open and pluralistic national community.

\section{NOTES}

1. Kathryn A. Conrad, Locked in the Family Cell: Gender, Sexuality, and Political Agency in Irish National Discourse, Madison, University of Wisconsin Press, 2004, p. 70-71. 
2. Elleke Boehmer, Stories of Women: Gender and Narrative in the Postcolonial Nation, Manchester, Manchester University Press, 2005, p. 4-5, 7.

3. This is apropos considering the 1937 Constitution of the Irish Republic linked women to hearth and home.

4. Sigmund Freud, The Uncanny, David McLintock (trans.), New York, Penguin Books, 2003, p. 132.

5. The novel was published the same year the IRA declared a cease-fire in Northern Ireland.

6. Joe Cleary, Literature, Partition and the Nation-State: Culture and Conflict in Ireland, Israel and Palestine, Oxford/New York, Cambridge University Press, p. 102.

7. Ibid., p. 100.

8. Julia Kristeva, Strangers to Ourselves, Leon S. Roudiez (trans.), New York, Columbia University Press, 1991, p. 183-184.

9. Jean and John Comaroff, "Criminal Obsessions, after Foucault: Postcoloniality, Policing, and the Metaphysics of Disorder," Critical Inquiry 30.4 (Summer 2004), p. 805.

10. Sara Mills, Gender and Colonial Space, Manchester, Manchester University Press, 2005, p. 23.

11. Edward Soja, Thirdspace: Journeys to Los Angeles and Other Real-and-Imagined Places, Cambridge, Blackwell Publishers, 1996, p. 66.

12. Ibid., p. 79.

13. Ibid., p. 80 .

14. Ibid., p. 67-68, 80 .

15. Gloria Anzaldúa, Borderlands/La Frontera: The New Mestiza, Third Edition, San Francisco, Aunt Lute Books, 2007, p. 14.

16. Though Soja briefly acknowledges Anzaldúa's work as an important "postmodern spatial feminist critique", he does not actually explore the ways in which her work radically opens up new avenues of analyzing Thirdspace.

17. Edward Soja, qtd. in Daphne Spain, Gendered Spaces, Chapel Hill: University of North Carolina Press, 1992, p. 28.

18. Danine Farquharson and Bernice Schrank, "Blurring Boundaries, Intersecting Lives: History, Gender, and Violence in Edna O'Brien's House of Splendid Isolation”, Lisa Colletta and Maureen O'Connor (eds.), Wild Colonial Girl: Essays on Edna O'Brien, Madison, University of Wisconsin Press, 2006, p. 116.

19. Maryann Gialanella Valiulis, “Engendering Citizenship: Women's Relationship to the State in Ireland \& the United States in the Post-Suffrage Period", Maryann Gialanella Valiulis and Mary O’Dowd (eds.), Women \& Irish History, Dublin \& Niwot, CO, Wolfhound Press, The Irish American Book Company, 1997, p. 161.

20. Catherine Nash, "Remapping the Body/Land: New Cartographies of Identity, Gender, and Landscape in Ireland," Alison Blunt and Gillian Rose (eds.), Writing Women and Space: Colonial and Postcolonial Geographies, New York: The Guilford Press, 1994, p. 237

21. Danine Farquharson and Bernice Schrank, op. cit., p. 120.

22. Elizabeth Steiner-Scott, “To Bounce a Boot Off Her Now \& Then...”: Domestic Violence in Post-Famine Ireland", Maryann Gialanella Valiulis and Mary O’Dowd (eds.), Women \& 
Irish History, Dublin \& Niwot, CO, Wolfhound Press, The Irish American Book Company, 1997, p. 143.

23. Edna O'Brien, House of Splendid Isolation, New York, Farrar, Straus and Giroux, 1994, p. 47. Henceforth this novel will be referenced in the body of the text.

24. O'Brien has written on the various female tropes used to represent Ireland in her memoir Mother Ireland (1976).

25. Soja, op. cit., p. 110.

26. Barbara Hooper, quoted in Soja, Ibid., 114.

27. Women's writing usually leads to miscommunication and often results in violence elsewhere in O'Brien's trilogy.

28. Comaroff, op.cit., 808.

29. Freud, op.cit., p. 143.

30. Cleary, op.cit., p. 23.

31. Ibid., p. 23.

32. Ibid., p. 23.

33. See Jennifer A. Slivka, "Irishness and Exile in Edna O'Brien's Wild Decembers and In the Forest”, New Hibernia Review 17.1 (Spring 2013), p. 115-131.

34. Kristeva, op. cit., p. 9.

35. Cleary, op.cit., p. 99-100.

36. Michael Harris, "Outside History: Relocation and Dislocation in Edna O'Brien's House of Splendid Isolation", Kathryn Laing, Sinead Mooney, and Maureen O'Connor (eds.), Edna O'Brien: New Critical Perspectives, Dublin, Carysfort Press, 2006, p. 128.

37. Laura Pelaschiar, "Terrorists and Freedom Fighters in Northern Irish Fiction," The Irish Review, 40/41 (Winter 2009), p. 58.

38. Harris, op. cit., p. 130.

39. Cleary, op.cit., p. 110-111, 113.

40. Homi Bhabha, "The World and the Home", Social Text No. 31/32, Third World and PostColonial Issues (1992), p. 147.

41. Cleary, op.cit., p. 98.

42. Sophia Hillan, "On the Side of Life: Edna O'Brien's Trilogy of Contemporary Ireland", Lisa Colletta and Maureen O'Connor (eds.), Wild Colonial Girl: Essays on Edna O'Brien, Madison, University of Wisconsin Press, 2006, p.149.

43. Ibid., p. 150.

44. Anzaldúa, op. cit., p. 71.

45. Ibid., p. 101.

46. Comaroff, op.cit. p. 803.

47. David Lloyd, Anomalous States: Irish Writing and the Post-Colonial Moment, Durham: Duke University Press, 1993, p. 19.

48. Ibid., p. 19.

49. Conrad, op. cit., p. 78.

50. Pelaschiar, op.cit., p. 53.

51. Lloyd, op.cit., p. 6. 


\section{ABSTRACTS}

In Edna O'Brien's House of Splendid Isolation (1994), the house, a microcosm for the nation, along with its marginalized occupants, reflect the borders between North and South, past and present. By critically interrogating the ways in which O'Brien's dilapidated Big House becomes an uncanny borderland, this essay unpacks the ways in which the Irish nation attempts to define itself by "evicting" those who disrupt the laws of state and gender.

\section{INDEX}

Mots-clés: Edna O’Brien, corps féminins, spatialité, littérature post coloniale, identité nationale, Irlande du Nord

Keywords: O'Brien Edna, women's bodies, spatiality, postcolonial literature, national identity, Northern Ireland

\section{AUTHOR}

\section{JENNIFER A. SLIVKA}

Dr. Jennifer A. Slivka is Associate Professor of English and Women's \& Gender Studies at Virginia Wesleyan University, where she is also Director of the Women's Resource Center. Jennifer researches the politics of identity, place, and trauma in contemporary Irish women's writing and teaches British and Post-colonial Literatures, along with Gender Theory. Her publications include "Irishness and Exile in Edna O'Brien's Wild Decembers and In the Forest" in New Hibernia Review and "History and the 'I' Trapped in the Middle: Negotiating the Past in Roth's The Ghost Writer and The Plot Against America" in Philip Roth Studies. 